\title{
Ginsenoside F1 Modulates Cellular Responses of Skin Melanoma Cells
}

\author{
Dae Sung Yoo ${ }^{1 \#}$, Ho Sik Rho" ${ }^{2 \#}$, Yong Gyu Lee ${ }^{1}$, Myung Hun Yeom ${ }^{2}$, Duck Hee Kim², Sang-Jin Lee \\ Sungyoul Hong ${ }^{3}$, Jaehwi Lee ${ }^{4^{*}}$, and Jae Youl Cho ${ }^{3^{*}}$ \\ ${ }^{1}$ College of Biomedical Science and Institute of Bioscience and Biotechnology, Kangwon National University, Chuncheon 200-701, \\ Korea \\ ${ }^{2}$ R\&D Center, Amore-Pacific Co., Yongin 446-729, Korea \\ ${ }^{3}$ Department of Genetic Engineering, Sungkyunkwan University, Suwon 440-746, Korea \\ ${ }^{4}$ College of Pharmacy, Chung-Ang University, Seoul 156-756, Korea
}

Ginsenoside (G)-F1 is an enzymatic metabolite generated from G-Rg1. Although this metabolite has been reported to suppress platelet aggregation and to reduce gap junction-mediated intercellular communication, the modulatory activity of G-F1 on the functional role of skin-derived cells has not yet been elucidated. In this study, we evaluated the regulatory role of G-F1 on the cellular responses of B16 melanoma cells. G-F1 strongly suppressed the proliferation of B16 cells up to $60 \%$ at $200 \mu \mathrm{g} / \mathrm{mL}$, while only diminishing the viability of HEK293 cells up to $30 \%$. Furthermore, G-F1 remarkably induced morphological change and clustering of B16 melanoma cells. The melanin production of B16 cells was also significantly blocked by G-F1 up to 70\%. Interestingly, intracellular signaling events involved in cell proliferation, migration, and morphological change were up-regulated at $1 \mathrm{~h}$ incubation but down-regulated at $12 \mathrm{~h}$. Therefore, our results suggest that G-F1 can be applied as a novel anti-skin cancer drug with anti-proliferative and anti-migration features.

Keywords: Panax ginseng, Ginsenoside F1, Experimental melanoma, Proliferation, Morphological change, Melanin production

\section{INTRODUCTION}

Melanocytes are melanin-producing cells located in the bottom layer of the skin epidermis [1]. Melanin, a pigment primarily responsible for the color of skin, is generated by melanogenesis in melanocytes. Exposure to UV-B radiation is known to cause increased melanogenesis as a response to DNA photodamage [2]. Some of the serious damage to oncogenic or tumor suppressor genes by free radicals generated can lead melanocytes to form the skin cancer melanoma, a representative malignant tumor in skin with a high death rate [3]. In spite of numerous intensive laboratory and clinical studies, early surgical resection of thin tumors still gives the greatest chance of a cure.

Panax ginseng, a perennial plant of Araliaceae, is a popular traditional herbal medicine prescribed for increased vitality, long life, supplement of spirits, and light (c) This is an Open Access article distributed under the terms of the Creative Commons Attribution Non-Commercial License (http://creativecommons.org/licenses/by-nc/3.0/) which permits unrestricted non-commercial use, distribution, and reproduction in any medium, provided the original work is properly cited.
Received 1 Nov. 2010, Revised 6 Nov. 2010, Accepted 10 Nov. 2010

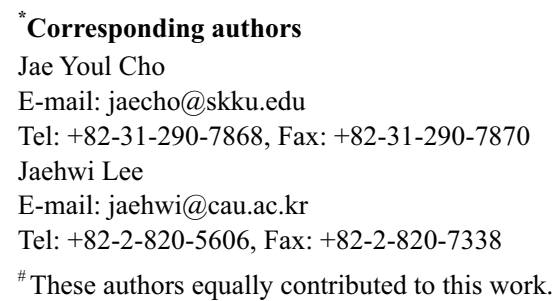




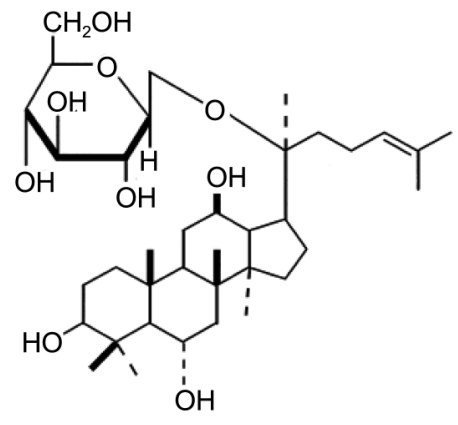

Fig. 1. Chemical structure of ginsenoside-F1.

bodies [4]. Regarding the different origins of ginseng, it has been reported that Korean ginseng (Panax ginseng) is one of the best types of ginseng in terms of active component contents. The pharmacological effects of ginseng mainly originate from ginseng saponins, in particular ginsenosides [5]. The pharmacological profile of ginseng includes curative or modulatory effects on cardiovascular disease, diabetes mellitus, cancer, stress, and immunostimulation [5]. Recent studies strongly suggest that the numerous pharmacological activities of ginseng could be managed by ginsenoside metabolites such as compound $\mathrm{K}$ and ginsenoside (G)-F1 [6,7].

G-F1 (Fig. 1) is one of the metabolites generated by enzymatic modification of G-Rg1 [8]. Although G-F1 is not the major metabolite of the ginsenosides found in the blood, the biological activity of ginseng could be in part derived from the pharmacology of G-F1. In spite of this possibility, only a few reports that this compound can suppress platelet aggregation [9] and reduce gap junction-mediated intercellular communication [10] have been reported. So far, several ginsenosides such as G-Rb1, G-Rh2, G-Rg3 and G-Rf as well as compound $\mathrm{K}$ have been reported to modulate skin diseases such as psoriasis and contact dermatitis [11,12]. However, whether G-F1 is able to modulate skin-derived cell functions has not yet been published. Therefore, in this study, we explored the regulatory role of G-F1 on the cellular responses of skin-derived cells using B16 melanoma.

\section{MATERIALS AND METHODS}

\section{Materials}

G-F1 was obtained from Amore-Pacific Co., R\&D Center (Yongin, Korea). The purity of these compounds was more than $95 \%$ by HPLC analysis. Arbutin was obtained from Sigma (St. Louis, MO, USA). B16 melanoma and HEK293 cells were purchased from American Type Culture Collection (Manassas, VA, USA). Phos- pho- or total antibodies to ERK, JNK, p38, Akt, and $\beta$-actin were purchased from Cell Signaling (Beverly, MA, USA).

\section{Cell culture}

B16 melanoma and HEK293 cells were cultured in Dulbecco's modified Eagle's medium or RPMI1640 with $10 \%$ fetal bovine serum and $100 \mathrm{U} / \mathrm{mL}$ penicillin/streptomycin at $37^{\circ} \mathrm{C}$ in a humidified atmosphere with $5 \%$ $\mathrm{CO}_{2}$.

\section{Cell proliferation assay}

Cell viability and the extent of proliferation were assessed by conventional MTT [3-(4,5-dimethylthiazol2-yl)-2,5-diphenyltetrazolum bromide] assay [13]. B16 and HEK293 cells $\left(5 \times 10^{4}\right.$ cells/well $)$ were incubated with various concentrations of G-F1 or arbutin for the indicated times and were further incubated with MTT solution $(0.5 \mathrm{mg} / \mathrm{mL})$ for an additional $4 \mathrm{~h}$ at $37^{\circ} \mathrm{C}$. The absorbance of the samples was measured at $490 \mathrm{~nm}$ with a microplate reader (Molecular Devices Corp., Menlo Park, CA, USA).

\section{Morphological change test}

B16 melanoma cells were incubated with G-F1 for the indicated times. Images of the cells in culture at each time point were obtained using an inverted phase contrast microscope, attached to a video camera, and captured using NIH Image (National Institutes of Health, Bethesda, MD, USA).

\section{Cell migration assay}

B16 melanoma cells grown to a confluent monolayer in $60-\mathrm{mm}$ plates were incubated with G-F1. A scratch was introduced by scraping the monolayer with a p200 pipette tip, as previously described [14]. The images were acquired using an inverted phase microscope (Olympus, Tokyo, Japan).

\section{Cellular melanin production assay}

B16 and HEK293 cells $\left(5 \times 10^{4}\right.$ cells/well $)$ were incubated with various concentrations of G-F1 or arbutin for 5 days. The cell pellets were then dissolved in a 500 $\mathrm{mL}$ solution of $1 \mathrm{~N} \mathrm{NaOH}$ in $10 \%$ dimethyl sulfoxide at $80^{\circ} \mathrm{C}$ for $1 \mathrm{~h}$. The relative melanin content was determined by measuring the absorbance at $475 \mathrm{~nm}$ in an ELISA reader (Molecular Devices Corp., Menlo Park, CA, USA). A standard synthetic melanin curve $(0-500$ $\mu \mathrm{g} / \mathrm{mL}$ ) was prepared in triplicate for each experiment. 


\section{Preparation of cell lysates and immunoblotting}

Melanoma cells $\left(5 \times 10^{6}\right.$ cells $\left./ \mathrm{mL}\right)$ treated with G-F1 were washed 3 times in cold phosphate-buffered saline with $1 \mathrm{mM}$ sodium orthovanadate and were lysed in lysis buffer (20 mM Tris-HCl, pH 7.4, 2 mM EDTA, 2 mM ethyleneglycotetraacetic acid, $50 \mathrm{mM} \beta$-glycerophosphate, $1 \mathrm{mM}$ sodium orthovanadate, $1 \mathrm{mM}$ dithiothreitol, $1 \%$ Triton X-100, 10\% glycerol, $10 \mu \mathrm{g} / \mathrm{mL}$ aprotinin, 10 $\mu \mathrm{g} / \mathrm{mL}$ pepstatin, $1 \mathrm{mM}$ benzimide, and $2 \mathrm{mM}$ PMSF) for $30 \mathrm{~min}$ with rotation at $4^{\circ} \mathrm{C}$. The lysates were clarified by centrifugation at $16,000 \mathrm{~g}$ for $10 \mathrm{~min}$ at $4^{\circ} \mathrm{C}$ and stored at $-20^{\circ} \mathrm{C}$ until needed.

Whole cell lysates were then analyzed by immunoblotting as reported previously $[15,16]$. Proteins were separated on $10 \%$ sodium dodecyl sulfate-polyacrylamide gels and were transferred by electroblotting to a polyvinylidenedifluoride membrane. Membranes were blocked for $60 \mathrm{~min}$ in Tris-buffered saline containing 3\% bovine serum albumin, $20 \mathrm{mM} \mathrm{NaF}, 2 \mathrm{mM}$ EDTA, and $0.2 \%$ Tween 20 at room temperature. The membrane was incubated for 60 min with specific primary antibody at $4^{\circ} \mathrm{C}$, washed 3 times with the same buffer, and incubated for an additional $60 \mathrm{~min}$ with horseradish peroxidaseconjugated secondary antibody. The total and phosphorylated levels of ERK, JNK, p38, Akt, and $\beta$-actin were visualized using the enhanced chemiluminescence system (Amersham, Little Chalfont, UK).

\section{Statistical analysis}

Student's $t$-test and a one-way ANOVA were used to determine the statistical significance of the difference between values for the various experimental and control groups. Data are expressed as mean \pm standard error, and the results were obtained from at least three independent experiments performed in triplicate. A $p$-value of 0.05 or less were considered as statistically significant.

\section{RESULTS AND DISCUSSION}

In this study, we explored the modulatory role of G-F1 (Fig. 1), an enzymatic metabolite of G-Rg1, on the cellular responses of skin melanocytes, specifically B16 melanoma, including proliferation, morphological change, cell migration and aggregation, melanogenesis, and intracellular signaling events. Interestingly, G-F1 significantly suppressed the proliferation of B16 melanoma up to $60 \%$ at $200 \mu \mathrm{g} / \mathrm{mL}$ (Fig. 2A). The proliferation of HEK293 cells was only slightly blocked by this compound up to $30 \%$ (Fig. 2B), suggesting that inhibition by G-F1 seems to be stronger in melanocyte-derived cancer
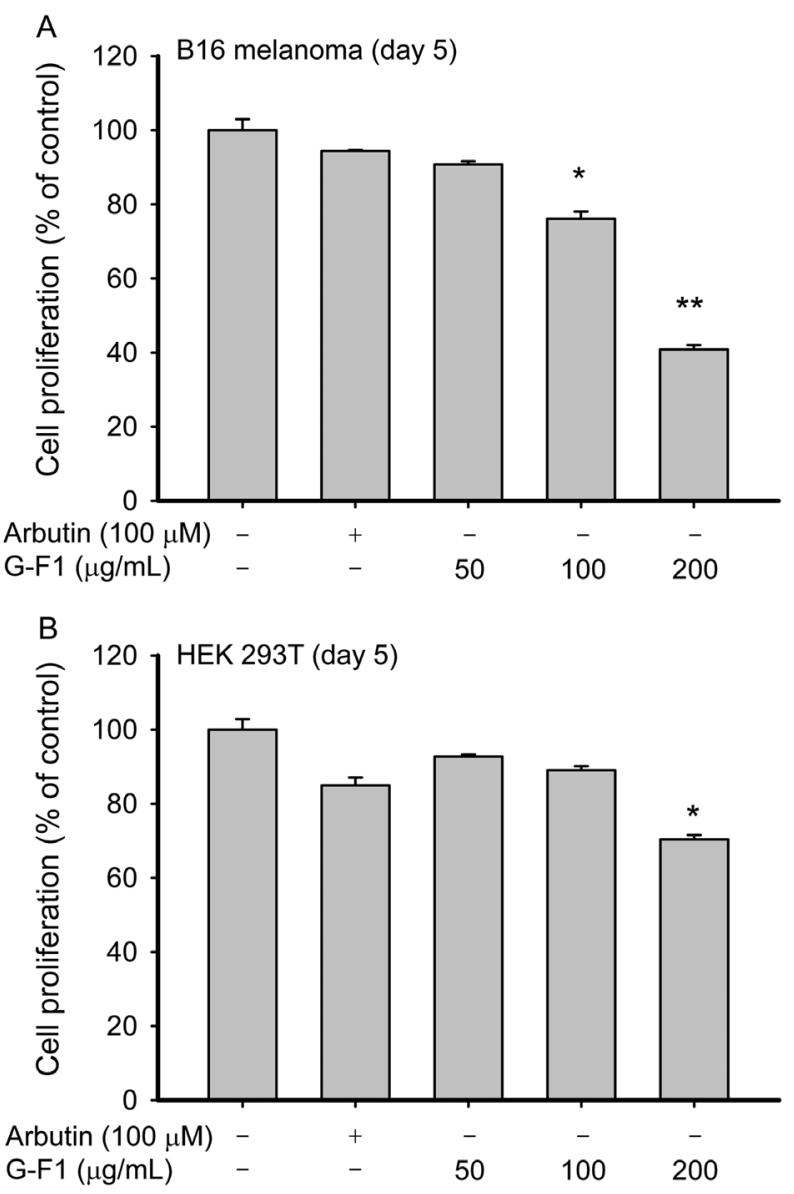

Fig. 2. Effect of ginsenoside (G)-F1 on cell proliferation in $B 16$ melanoma and HEK293 cells. (A,B) B16 or HEK293 cells $\left(1 \times 10^{6}\right.$ cells/ $\mathrm{mL}$ ) were incubated with G-F1 or arbutin for 5 days. Cell viability was determined by conventional MTT assay as described in the Materials and Methods section. " $p<0.05$ and " $p<0.01$ compared with normal.

cells. However, short treatment with this compound did not exhibit significant blockade of cell viability up to $200 \mu \mathrm{g} / \mathrm{mL}$ (data not shown), implying that long exposure to G-F1 can be effective for the regulation of melanoma cell proliferation. In fact, it has been reported that G-F1 significantly reduces ultraviolet-B-induced cell death and protects $\mathrm{HaCaT}$ cells from apoptosis caused by ultraviolet B irradiation [17]. Our data seem to suggest the opposite of this notion in terms of suppressing cell death. However, it appears that G-F1 treatment is likely to be beneficial under tumorigenic conditions of melanocytes.

Morphological change and migration are also very important cellular events when cancer cells need to metastatically move. As Figs. 3 and 4 indicate, G-F1 seems to induce morphological alteration and to increase cellular clustering between B16 melanoma compared with the normal group. Considering that the alteration of cell 


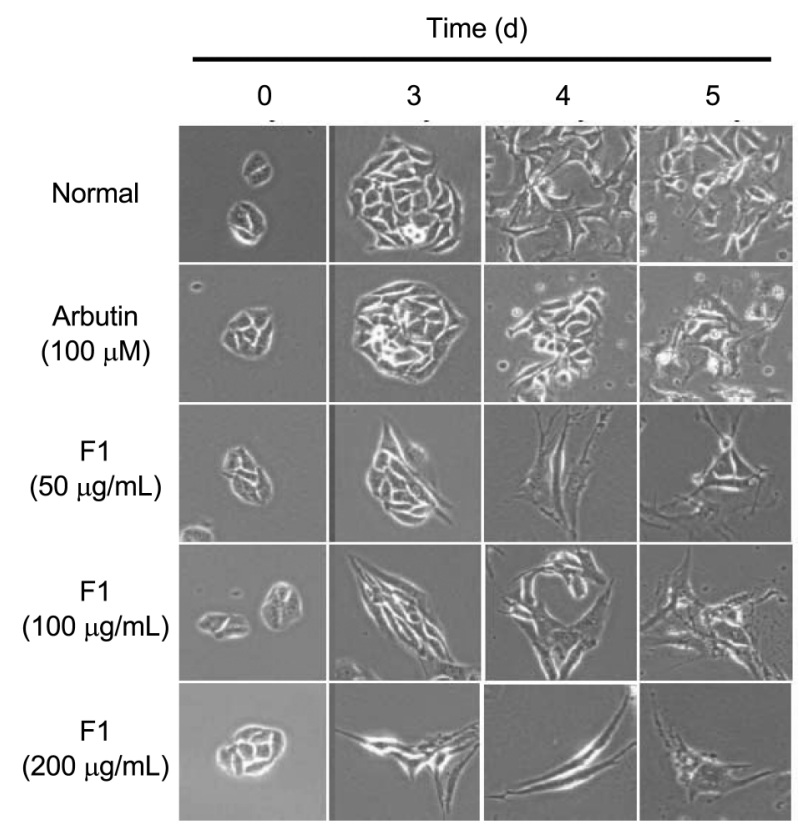

Fig. 3. Effect of ginsenoside (G)-F1 on morphological change in B16 melanoma cells. B16 melanoma cells $\left(1 \times 10^{5}\right.$ cells $\left./ \mathrm{mL}\right)$ were incubated with G-F1 for the times indicated. Images of the cells in culture at each time point were obtained using an inverted phase contrast microscope, attached to a video camera, and captured using $\mathrm{NIH}$ Image.

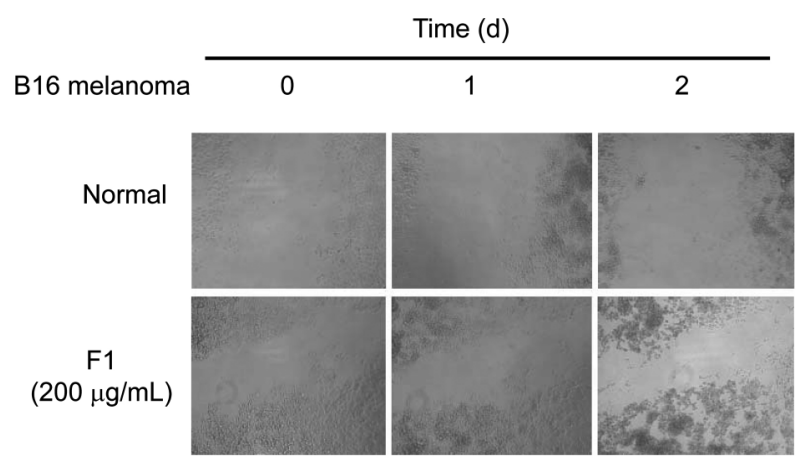

Fig. 4. Effect of ginsenoside-F1 on cell migration in B16 melanoma cells. B16 melanoma cells $\left(2 \times 10^{6}\right.$ cells $\left./ \mathrm{mL}\right)$ were grown to a confluent monolayer in $60-\mathrm{mm}$ plates. A scratch was introduced by scraping the monolayer with a p200 pipette tip. Images of the cells in culture at each time point were obtained using an inverted phase contrast microscope.

morphology is also linked to the induction of apoptosis [18], there is a possibility that G-F1-induced morphological change seems to cause both stimulation of apoptosis and induction of cell clustering. Although normal cells did not show a remarkable migration pattern, G-F1 treatment further stimulated the formation of cell clusters, suggesting that G-F1 $(200 \mu \mathrm{g} / \mathrm{mL})$ could modulate homotypic aggregation of B16 cells by altering morphological change. Since the morphological change and cell-cell adhesion has been found to be modulated by actin cytoskeleton change $[13,19,20]$, how G-F1 is capable

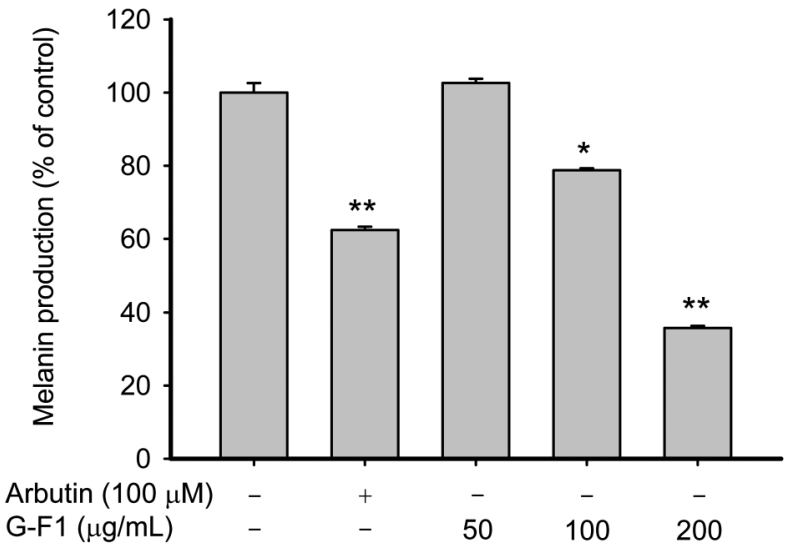

Fig. 5. Effect of ginsenoside $(\mathrm{G})-\mathrm{F} 1$ on melanin production in B16 melanoma cells. B16 or HEK293 cells $\left(1 \times 10^{6}\right.$ cells $\left./ \mathrm{mL}\right)$ were incubated with G-F1 or arbutin for 5 days. Melanin production was determined by cellular melanin production assay as described in the Materials and Methods section. " $p<0.05$ and " $p<0.01$ compared with normal.

of stimulating actin cytoskeleton rearrangement will be further studied.

Melanogenesis is a primary function of melanocytes to protect skin from UV irradiation [21]. However, since Far East Asian women dislike this protective response that leads to skin darkness, whitening potential should become an essential function in cosmetic industry. To confirm whether G-F1 has whitening functionality, G-F1 was long exposed to $\mathrm{B} 16$ cells, and the level of melanin in cultured cells was determined. As Fig. 5 depicts, G-F1 significantly diminished the production of melanin. Similarly, arbutin, a standard drug used for inhibition of melanogenesis [22], also suppressed melanin generation, suggesting that the experimental conditions were acceptable. Even though there is a possibility that G-F1mediated pigmenting inhibition seems to be derived by its cytotoxicity, this result implicates its potential usage as one of ingredients applicable for whitening purposes. Thus, there is a $15 \%$ difference in terms of inhibitory activity between cytotoxicity and melanin production assays. Therefore, it is thought that the inhibition of melanin production seems to be independent of the drug's cytotoxicity. We will further examine this point in the future work.

Cellular responses stimulated by chemical and biochemical stimulation accompany intracellular signaling events $[15,23]$. In general, the inhibition of cell proliferation, induction of cell cytoskeleton changes, and suppression of melanin generation by treatment with G-F1 could be managed either by G-F1-induced signaling or by G-F1 mediated inhibition of the cellular signaling cascade. Therefore, we finally investigated the effect of G-F1 on 
intracellular signaling in B16 melanoma cells in terms of MAPK (ERK, JNK, and p38) and Akt that are involved in the modulation of cell proliferation and morphological changes [15,24]. As Fig. 6 shows, the activation or inhibition of MAPK and Akt by G-F1 were variable. Thus, ERK, JNK, and Akt were activated between $1 \mathrm{~h}$ and $9 \mathrm{~h}$ of incubation with G-F1, while this compound suppressed the phosphorylation of ERK and Akt at $12 \mathrm{~h}$ of incubation. These data suggest that G-F1 can modulate the intracellular signaling cascade composed of MAPK and survival signaling by Akt. However, how this compound can increase the activation of such enzymes or how the signaling cascade can be suppressed by G-F1 have not yet been elucidated. Therefore, further experiments will be continued to address these questions.

Conclusively, in this study, we found that G-F1 was able to suppress the proliferation of B16 cells, induction of morphological changes, and production of melanin, and G-F1 was able to modulate the clustering of B16 cells and the intracellular signaling cascade. Therefore, our results suggest that G-F1 can be applied as a novel skin cancer drug with anti-proliferation, anti-migration, and whitening functions. Further in vivo efficacy test and molecular mechanism studies will be continued in the next project.

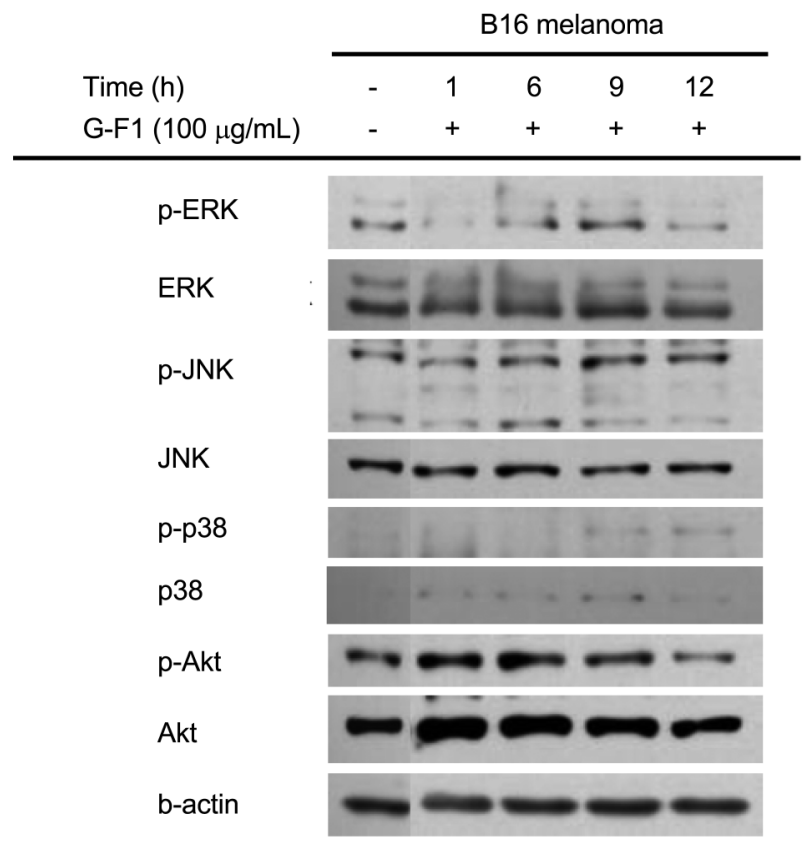

Fig. 6. Effect of ginsenoside (G)-F1 on the activation of signaling enzymes involved in cell survival and proliferation. B16 cells $\left(5 \times 10^{6}\right.$ cells $/ \mathrm{mL}$ ) were incubated with G-F1 for the times indicated. After immunoblotting, total or phospho-protein levels of ERK, p38, JNK, Akt, and b-actin were identified with their total protein- or phosphospecific antibodies.

\section{REFERENCES}

1. Meyskens FL Jr, Farmer P, Fruehauf JP. Redox regulation in human melanocytes and melanoma. Pigment Cell Res 2001;14:148-154.

2. Wood JM, Gibbons NC, Schallreuter KU. Melanocortins in human melanocytes. Cell Mol Biol (Noisy-le-grand) 2006;52:75-78.

3. Slominski A, Wortsman J, Carlson AJ, Matsuoka LY, Balch CM, Mihm MC. Malignant melanoma. Arch Pathol Lab Med 2001;125:1295-1306.

4. Hasani-Ranjbar S, Nayebi N, Larijani B, Abdollahi M. A systematic review of the efficacy and safety of herbal medicines used in the treatment of obesity. World J Gastroenterol 2009;15:3073-3085.

5. Hasegawa $\mathrm{H}$. Proof of the mysterious efficacy of ginseng: basic and clinical trials: metabolic activation of ginsenoside: deglycosylation by intestinal bacteria and esterification with fatty acid. J Pharmacol Sci 2004;95:153-157.

6. Wakabayashi C, Murakami K, Hasegawa H, Murata J, Saiki I. An intestinal bacterial metabolite of ginseng protopanaxadiol saponins has the ability to induce apoptosis in tumor cells. Biochem Biophys Res Commun 1998;246:725-730.

7. Choo MK, Sakurai H, Kim DH, Saiki I. A ginseng saponin metabolite suppresses tumor necrosis factor-alpha-promoted metastasis by suppressing nuclear factor-kappaB signaling in murine colon cancer cells. Oncol Rep 2008;19:595600.

8. Ko SR, Choi KJ, Uchida K, Suzuki Y. Enzymatic preparation of ginsenosides $\mathrm{Rg} 2, \mathrm{Rh} 1$, and F1 from protopanaxatriol-type ginseng saponin mixture. Planta Med 2003;69:285-286.

9. Wang J, Huang ZG, Cao H, Wang YT, Hui P, Hoo C, Li SP. Screening of anti-platelet aggregation agents from Panax notoginseng using human platelet extraction and HPLCDAD-ESI-MS/MS. J Sep Sci 2008;31:1173-1180.

10. Zhang YW, Dou DQ, Zhang L, Chen YJ, Yao XS. Effects of ginsenosides from Panax ginseng on cell-to-cell communication function mediated by gap junctions. Planta Med 2001;67:417-422.

11. Shin YW, Bae EA, Kim SS, Lee YC, Kim DH. Effect of ginsenoside $\mathrm{Rb} 1$ and compound $\mathrm{K}$ in chronic oxazoloneinduced mouse dermatitis. Int Immunopharmacol 2005;5: 1183-1191.

12. Shin YW, Bae EA, Kim DH. Inhibitory effect of ginsenoside $\operatorname{Rg} 5$ and its metabolite ginsenoside $\mathrm{Rh} 3$ in an oxazolone-induced mouse chronic dermatitis model. Arch Pharm Res 2006;29:685-690.

13. Cho JY, Fox DA, Horejsi V, Sagawa K, Skubitz KM, Katz DR, Chain B. The functional interactions between CD98, 
beta1-integrins, and CD147 in the induction of U937 homotypic aggregation. Blood 2001;98:374-382.

14. Lee YW, Kim PH, Lee WH, Hirani AA. Interleukin-4, oxidative stress, vascular inflammation and atherosclerosis. Biomol Ther 2010;18:135-144.

15. Lee JY, Lee YG, Lee J, Yang KJ, Kim AR, Kim JY, Won MH, Park J, Yoo BC, Kim S, et al. Akt Cys-310-targeted inhibition by hydroxylated benzene derivatives is tightly linked to their immunosuppressive effects. J Biol Chem 2010;285:9932-9948.

16. Shim JH, Choi CS, Lee EC, Kim MY, Chun YJ. Tamoxifen suppresses clusterin level through Akt inactivation and proteasome degradation in human prostate cancer cells. Biomol Ther 2009;17:25-31.

17. Lee EH, Cho SY, Kim SJ, Shin ES, Chang HK, Kim DH, Yeom MH, Woe KS, Lee J, Sim YC, et al. Ginsenoside $\mathrm{F} 1$ protects human $\mathrm{HaCaT}$ keratinocytes from ultravioletB-induced apoptosis by maintaining constant levels of Bcl-2. J Invest Dermatol 2003;121:607-613.

18. Niederman R, Amrein PC, Hartwig J. Three-dimensional structure of actin filaments and of an actin gel made with actin-binding protein. J Cell Biol 1983;96:1400-1413.
19. Cho JY, Katz DR, Chain BM. Staurosporine induces rapid homotypic intercellular adhesion of U937 cells via multiple kinase activation. Br J Pharmacol 2003;140:269276.

20. Cho JY, Chain BM, Vives J, Horejsi V, Katz DR. Regulation of CD43-induced U937 homotypic aggregation. Exp Cell Res 2003;290:155-167.

21. Park HY, Kosmadaki M, Yaar M, Gilchrest BA. Cellular mechanisms regulating human melanogenesis. Cell Mol Life Sci 2009;66:1493-1506.

22. Virador VM, Kobayashi N, Matsunaga J, Hearing VJ. A standardized protocol for assessing regulators of pigmentation. Anal Biochem 1999;270:207-219.

23. Lee YG, Lee WM, Kim JY, Lee JY, Lee IK, Yun BS, Rhee MH, Cho JY. Src kinase-targeted anti-inflammatory activity of davallialactone from Inonotus xeranticus in lipopolysaccharide-activated RAW264.7 cells. Br J Pharmacol 2008; 154:852-863.

24. Cho JY, Kim AR, Joo HG, Kim BH, Rhee MH, Yoo ES, Katz DR, Chain BM, Jung JH. Cynaropicrin, a sesquiterpene lactone, as a new strong regulator of CD29 and CD98 functions. Biochem Biophys Res Commun 2004;313:954-961. 